\title{
PEMETAAN TINGKAT BAHAYA EROSI BERDASARKAN METODE USLE DENGAN STUDI KASUS SIMULASI BERBAGAI TANAMAN DI DESA TAMBI KABUPATEN WONOSOBO
}

\section{(MAPPING THE LEVEL OF EROSION HAZARD BASED ON USLE METHOD WITH CASE STUDY OF VARIOUS PLANTS SIMULATION IN TAMBI VILLAGE WONOSOBO REGENCY)}

\author{
Imam Syaputra ${ }^{1)}$, Didi Saidi ${ }^{2 *}$, dan Yanisworo Wijaya Ratih ${ }^{2)}$ \\ ${ }^{1)}$ Prodi Agroteknologi, Universitas Pembangunan Nasional Veteran Yogyakarta \\ ${ }^{2}$ Prodi Ilmu Tanah, Universitas Pembangunan Nasional Veteran Yogyakarta \\ ${ }^{*}$ Corresponding author E-mail: didi.saidi@upnyk.ac.id
}

\begin{abstract}
Tambi Village is an area that has high potential for erosion because of its climate, soil condition, and not optimal conservation. This research aims to (a.) know the soil erosion rate and the erosion hazard in Tambi Village and (b.) to know the effects of the various plants simulation of the erosion hazard in Tambi Village. The methods used in this research are the survey method, with a purposive sampling method as the sampling method, and the USLE method to estimate the erosion rate. The simulation of erosion hazard used 4 kinds of plants, they are Jogo Beans, Potato, Tea, and Albizia. The maps were created by using a software named Arcgis 10.2. The sampling points obtained by overlaying land system maps such as land use map and slope map. This research obtained 11 sampling points. The parameter that used in this research were erosivity of rain (R), soil erodibility $(\mathrm{K})$ including texture, structure, permeability, and the organic matter of soil, the length and the steepness of slope (LS), the surface plants (C), the land management $(\mathrm{P})$, and the depth of solum. The result of this research has shown that the highest rate of erosion is 561,19 ton/ha/year which has an area of 9,56 ha $(6,01 \%)$, meanwhile the lowest rate of erosion is 0,5 ton/ha/year which has an area of 13,30 ha $(8,36 \%)$. Tambi Village has 22,66 hectares of low erosion level, 99,18 hectares of moderate erosion level, 7,3 hectares of heavy erosion level, and 29,91 hectares of very heavy erosion level. The result of the various plants simulation affects both the erosion rate and erosion hazard classification.
\end{abstract}

Keywords: erosion, hazard, map, simulation, Tambi, USLE

\begin{abstract}
ABSTRAK
Desa Tambi merupakan kawasan yang memiliki potensi erosi yang tinggi karena iklim, kondisi tanah, dan konservasi yang belum optimal. Penelitian ini bertujuan untuk (a.) Mengetahui laju erosi tanah dan bahaya erosi di Desa Tambi dan (b.) Mengetahui pengaruh simulasi berbagai tanaman terhadap bahaya erosi di Desa Tambi. Metode yang digunakan dalam penelitian ini adalah metode survei, dengan metode pengambilan sampel purposive sampling, dan metode USLE untuk memperkirakan laju erosi. Simulasi
\end{abstract}


bahaya erosi menggunakan 4 jenis tumbuhan yaitu Jogo Beans, Potato, Tea, dan Albizia. Peta dibuat dengan menggunakan perangkat lunak bernama Arcgis 10.2. Titik pengambilan sampel diperoleh dengan melakukan overlay peta sistem lahan seperti peta tata guna lahan dan peta kemiringan lereng. Penelitian ini memperoleh 11 titik pengambilan sampel. Parameter yang digunakan dalam penelitian ini adalah erosivitas hujan $(\mathrm{R})$, erodibilitas tanah $(\mathrm{K})$ meliputi tekstur, struktur, permeabilitas, dan bahan organik tanah, panjang dan kemiringan lereng (LS), tanaman permukaan (C). ), pengelolaan lahan $(\mathrm{P})$, dan kedalaman solum. Hasil penelitian menunjukkan laju erosi tertinggi adalah 561,19 ton/ha/tahun dengan luas wilayah 9,56 ha $(6,01 \%)$, sedangkan laju erosi terendah 0,5 ton /tahun, memiliki luas 13,30 ha $(8,36 \%)$. Desa Tambi memiliki tingkat erosi rendah 22,66 hektar, tingkat erosi sedang 99,18 hektar, tingkat erosi berat 7,3 hektar, dan tingkat erosi sangat berat 29,91 hektar. Hasil simulasi berbagai tumbuhan mempengaruhi baik laju erosi maupun klasifikasi bahaya erosi.

Kata kunci: erosi, rawan, peta, simulasi, Tambi, USLE

\section{PENDAHULUAN}

Erosi adalah hilang atau terkikisnya tanah atau bagian-bagian tanah dari suatu tempat ke tempat yang lain. Pada umumnya erosi yang terjadi oleh air lebih besar dibandingkan dengan erosi oleh angin di daerah beriklim basah seperti Indonesia. Erosi menyebabkan hilangnya lapisan tanah yang subur dan baik untuk pertumbuhan tanaman serta berkurangnya kemampuan tanah untuk menyerap dan menahan air (Arsyad, 1989).

Erosi dapat disebabkan karena aktivitas alam maupun karena aktivitas manusia. Peristiwa erosi yang terjadi secara alami tidak terlalu banyak menimbulkan masalah, namun peristiwa erosi karena manusia dapat menimbulkan berbagai masalah kerusakan atau degradasi lahan dan mengalami percepatan laju erosi. Proses erosi terdisi atas tiga bagian yang berurutan: dispersi (detachment), pengangkutan (transportation), dan pengendapan (sedimentation) (Alie, 2015). Faktor iklim yang berpengaruh terhadap erosi tanah adalah hujan, temperatur, dan suhu. Sejauh ini hujan merupakan faktor yang terpenting. Terdapat dua penyebab utama terjadinya erosi, yaitu tetesan air hujan dan aliran permukaan. Karekteristik hujan yang mempunyai pengaruh terhadap erosi tanah meliputi jumlah, intesitas hujan dan lamanya hujan.

Secara fisik tanah terdiri dari partikel mineral dan organik dari berbagai ukuran. Partikel-partikel tersebut terdiri dari bentuk matrik yang oriporinya kurang dari $50 \%$, sebagian terisi air dan sebagian lagi terisi oleh udara. Dalam kaitanya konservasi tanah dan air, faktor yang perpengaruh adalah: tekstur, struktur, infiltrasi dan kandungan bahan organik. Laju erosi akan meningkat apabila lereng semakin curam atau semakin panjang. Apabila lereng semakin curam maka kecepatan aliran permukaan meningkat sehingga kekuatan mengangkut meningkat pula. Lereng yang semakin panjang menyebabkan volume air yang mengalir menjadi semakin besar

Vegetasi mampu menangkap atau intersepsi air hujan, sehingga energi kinetiknya tidak langsung menghantam permukaan tanah. Pengaruh intersepsi air hujan oleh tumbuhan pada erosi melalui dua cara yaitu memotong secara langsung air hujan sehingga tidak langsung jatuh kepermukaan tanah dan memberikan kesempatan penguapan secara langsung dari dedaunan dan dahan, sehingga dapat meminimalkan pengaruh negatif pada stuktur tanah. Perakaran tanaman meningkatkan stabilitas tanah dengan meningkatkan 
kekuatan tanah, granulitas dan porositas. Aktivitas biologi yang berkaitan dengan pertumbuhan tanaman memberikan dampak positif pada porositas tanah. Tanaman mendorong transpirasi air sehingga lapisan tanah atas lebih kering dan memadatkan lapisan di bawahnya

Kepekaan tanah terhadap erosi dapat diubah oleh manusia menjadi lebih baik atau lebih buruk. Pembuatan teras-teras pada tanah yang berlereng curam merupakan pengaruh baik dari manusia karena dapat mengurangi erosi. Sebaliknya penggundulan hutan di daerah-daerah pegunungan merupakan pengaruh manusia yang buruk karena dapat menyebabkan erosi (Suripin, 2001).

Universal Soil Loss Equation (USLE) adalah suatu persamaan untuk memperkirakan kehilangan tanah yang telah dikembangkan oleh Smith dan Wischmeier tahun 1978. Metode USLE digunakan dengan menggunakan variabel- variabel yang sangat berpengaruh terhadap besarnya kehilangan tanah yang dapat diperhitungkan secara terperinci. Persamaan USLE tersebut dijelaskan sebagai berikut:

$\mathrm{A}=\mathrm{R} \times \mathrm{K} \times \mathrm{LS} \times \mathrm{C} \times \mathrm{P}$ Keterangan:

$\mathrm{A}=$ Laju erosi tanah (ton/ha/th) $\mathrm{R}=$ Erosivitas hujan

$\mathrm{K}=$ Erodibilitas tanah

LS = Panjang dan kemiringan lereng $\mathrm{C}=$ Vegetasi (penggunaan lahan)

$\mathrm{P}=$ Tindakan Konservasi (Arsyad, 1989)

Menurut Pemeritah Desa Tambi (2017), Desa Tambi memliki luas wilayah sebesar 188,936 ha yang terdistribusikan dalam berbagai macam penggunaan lahan. Sebagian besar wilayah Desa Tambi digunakan sebagai tegalan/kebun campuran dengan luasan sebesar 57,277 ha. Pemanfaatan lahan sebagai tegalan/kebun campuran tanpa dikelola dengan baik oleh masyarakat memicu timbulnya permasalahan seperti erosi dan tanah longsor. Selain itu, faktor pemicu erosi juga disebabkan karena tingginya curah hujan rata-rata tahunan yang sebesar $3374 \mathrm{~mm}$ dengan kondisi topografi yang berbukit-bukit.

\section{BAHAN DAN METODE}

Penelitian dilaksanakan di Desa Tambi Kecamatan Kejajar Kabupaten Wonoso. Analisis sampel tanah dilakukan di Laboratorium Fakultas Pertanian Universitas Pembangunan Nasional "Veteran" Yogyakarta. Alat yang digunakan adalah perengkat komputer, ArcGis 10.2, Microsoft Office 2013, bor tanah, ring sample, klinometer, plastik sampel, kompas, GPS, meteran, kamera, alat laboratorium. Bahan yang digunakan adalah peta kemiringan lereng dan tata guna lahan Desa Tambi skala 1:10.000, data curah hujan 10 tahun terakhir Desa Tambi, bahan kemikalia laboratorium, sampel tanah. Metode Penelitian ini menggunakan metode survey. Pendugaan/prediksi laju erosi pada lokasi penelitian dilakukan menggunakan metode USLE (Universal Soil Loss Equation) sedangkan dalam menentukan titik sampel dilakukan dengan sengaja atau dengan metode purposive sampling berdasarkan Sistem Lahan yang terbentuk dari overlay peta kemiringan lereng dan peta tata guna lahan Desa Tambi. Jumlah titik sampel yang ditentukan adalah sebanyak 11 titik. Peta tingkat bahaya erosi dibuat menggunakan sistem informasi geografis (software Arcgis 10.2). Parameter Penelitian meliputi Struktur Tanah, Kemiringan Lereng, Panjang Lereng, Keadaan Vegetasi, Metode Konservasi, Kedalaman Solum Tanah, Tekstur Tanah, Permeabilitas Tanah Kadar C-Organik. 


\section{HASIL DAN PEMBAHASAN}

\section{Erosivitas Hujan (R)}

Data curah hujan didapatkan dari PT. Perkebunan Tambi selama 10 tahun terakhir (tahun 2009-2018). Berdasarkan data yang didapatkan, erosivitas hujan dianalisis menggunakan rumus Lenvain (1975). Erosivitas hujan rata-rata selama 10 tahun terakhir adalah 2737,10 dengan rincian pada Tabel 1.

Tabel 1. Data Erosivitas Hujan (R) Desa Tambi

\begin{tabular}{cccc}
\hline No & Bulan & Rerata Curah Hujan $(\mathbf{c m})$ & Rm \\
\hline 1 & Januari & 46,58 & 410,34 \\
2 & Februari & 52,83 & 486,98 \\
3 & Maret & 47,54 & 421,88 \\
4 & April & 34,29 & 270,53 \\
5 & Mei & 19,45 & 125,12 \\
6 & Juni & 12,40 & 67,83 \\
7 & Juli & 4,97 & 19,56 \\
8 & Agustus & 5,39 & 21,85 \\
9 & September & 9,65 & 48,23 \\
10 & Oktober & 16,68 & 101,53 \\
11 & November & 34,59 & 273,76 \\
12 & Desember & 53,03 & 489,49 \\
\hline \multicolumn{2}{c}{ Total } \\
\hline
\end{tabular}

\section{Erodibilitas Tanah (K)}

Erodibilitas Tanah (K) Desa Tambi didapatkan dari analisa laboratorium dari setiap sampel tanah. Nilai Erodibilitas tanah (K) dihitung menggunakan persamaan Hammer (1978, dalam Hardjowigeno dan Sukmana 1995). Nilai erodibilitas tanah dipengaruhi oleh faktor tekstur, kandungan bahan organik, struktur, dan permeabilitas tanah. Nilai erodibilitas tanah secara keseluruhan dapat di lihat pada Tabel 2.

Tabel 2. Nilai Erodibilitas Tanah (K) Desa Tambi

\begin{tabular}{cccc}
\hline TS & Satuan Lahan & Nilai K & Kelas K \\
\hline 1 & LT-L & 0,60 & ST \\
2 & T-AC & 0,25 & $\mathrm{~S}$ \\
3 & LT-D & 0,49 & $\mathrm{~T}$ \\
4 & LT-AC & 0,55 & $\mathrm{~T}$ \\
5 & KC-AC & 0,62 & $\mathrm{ST}$ \\
6 & KC-L & 0,45 & $\mathrm{~T}$ \\
7 & LT-C & 0,39 & $\mathrm{AT}$ \\
8 & KC-C & 0,32 & $\mathrm{~S}$ \\
9 & H-AC & 0,31 & $\mathrm{~S}$ \\
10 & H-C & 0,26 & $\mathrm{~S}$ \\
11 & T-L & 0,26 & $\mathrm{~S}$ \\
\hline Keterangan: & ST $=$ Sangat Tinggi, T $=$ Tinggi, AT = Agak Tinggi, S =
\end{tabular}




\section{Panjang dan Kemiringan Lereng (LS)}

Nilai LS didapatkan dari pengamatan lapangan menggunakan alat ukur Meteran dan Klinometer. Untuk mendapatkan nilai LS maka data yang didapat dari pengamatan di lapangan di analisis menggunakan persamaan menurut Hardjowigeno dan Sukmana (1995), sehingga Nilai LS pada keseluruhan titik sampel dapat dilihat pada Tabel 3.

Tabel 3. Nilai Panjang dan Kemiriningan Lereng (LS) Desa Tambi

\begin{tabular}{clccc}
\hline TS & Satuan Lahan & Panjang $(\mathbf{m})$ & Kelerengan $(\%)$ & Nilai LS \\
\hline 1 & LT-L & 43 & 8,75 & 2,96 \\
2 & T-AC & 44 & 17,63 & 5,19 \\
3 & LT-D & 48 & 6,99 & 2,67 \\
4 & LT-AC & 36 & 15,84 & 4,30 \\
5 & KC-AC & 26 & 15,84 & 3,65 \\
6 & KC-L & 41 & 8,75 & 2,89 \\
7 & LT-C & 86 & 32,49 & 12,39 \\
8 & KC-C & 35 & 26,79 & 6,65 \\
9 & H-AC & 56 & 17,63 & 5,86 \\
10 & H-C & 167 & 36,29 & 19,09 \\
11 & T-L & 65 & 10,51 & 4,17 \\
\hline
\end{tabular}

\section{Vegetasi $(C)$}

Jenis vegetasi di Desa Tambi cukup beragam. Tidak hanya tanaman hortikultura tetapi juga banyak terdapat tanaman perkebunan seperti teh dan tembakau. Nilai $\mathrm{C}$ didapatkan berdasarkan pengamatan lapangan dan mencari padanannya berdasarkan tabel Nilai $\mathrm{C}$ dari 3 sumber yaitu menurut Departemen Kehutanan (1998), Pedoman RTKRHT- DAS (2009), dan Ashari (2012). Sehingga nilai $C$ pada Desa Tambi dapat dilihat pada Tabel 4.

Tabel 4. Nilai Vegetasi (C) Desa Tambi

\begin{tabular}{cccc}
\hline TS & Satuan Lahan & Jenis Vegetasi & Nilai C \\
\hline 1 & LT-L & Kacang jogo & $0,161^{* *}$ \\
2 & T-AC & Teh & $0,35^{*}$ \\
3 & LT-D & Kentang searah kontur & $0,35^{* *}$ \\
4 & LT-AC & Wortel & $0,26^{* * *}$ \\
5 & KC-AC & Tembakau & $0,6^{*}$ \\
6 & KC-L & Wortel & $0,26^{* * *}$ \\
7 & LT-C & Semak Belukar & $0,01^{*}$ \\
8 & KC-C & Tembakau & $0,6^{*}$ \\
9 & H-AC & Hutan Produksi & $0,001^{*}$ \\
10 & H-C & Hutan Produksi & $0,001^{*}$ \\
11 & T-L & Teh & $0,35^{*}$ \\
\hline
\end{tabular}

Keterangan:

$$
\begin{array}{ll}
* & =\text { Departemen Kehutanan (1998) } \\
* * & =\text { Pedoman RTkRHL-DAS (2009) } \\
* * * & =\text { Ashari (2012) }
\end{array}
$$




\section{Tindakan Konservasi (P)}

Tindakan Konservasi di Desa Tambi didapatkan berdasarkan pengamatan lapangan dan mencari padanannya berdasarkan tabel Nilai P dari 2 sumber yaitu menurut Pedoman RTKRHT-DAS (2009) dan Abdukrahman, et al (1981). Sehingga nilai P di Desa Tambi dapat dilihat pada Tabel 5.

Tabel 5. Nilai tindakan konservasi (P) Desa Tambi

\begin{tabular}{clll}
\hline TS & Satuan Lahan & \multicolumn{1}{c}{ Jenis Konservasi } & \multicolumn{1}{c}{ Indeks Nilai P } \\
\hline 1 & LT-L & Bedengan & $0,15^{* *}$ \\
2 & T-AC & Tanaman Perkebunan & $0,1^{*}$ \\
3 & LT-D & Bedengan & $0,15^{* *}$ \\
4 & LT-AC & Bedengan & $0,15^{* *}$ \\
5 & KC-AC & Teras Sedang & $0,15^{*}$ \\
6 & KC-L & Teras Sedang & $0,15^{*}$ \\
7 & LT-C & Teras Jelek & $0,35^{*}$ \\
8 & KC-C & Teras Sedang & $0,15^{*}$ \\
9 & H-AC & Penutup Tanah Rapat & $0,1^{*}$ \\
10 & H-C & Penutup Tanah Rapat & $0,1^{*}$ \\
11 & T-L & Tanaman Perkebunan & $0,1^{*}$ \\
\hline
\end{tabular}

Keterangan:

$*$ = Abdukrahman, et al (1981); **= Pedoman RTkRHL-DAS (2009)

\section{Prediksi Laju Erosi (A) dan Klasifikasi Tingkat Bahaya Erosi}

Analisis prediksi laju erosi (A) dilakukan dengan menggunakan metode USLE (Universal Soil Loss Equation) dimana besar laju erosi dipengaruhi faktor- faktor penyebab erosi seperti erosivitas hujan (R), erodibilitas tanah (K), kemiringan dan panjang lereng (LS), faktor vegetasi (C), serta tindakan konservasi (P). Kelas Tingkat Bahaya Erosi (TBE) ditentukan berdasarkan tabel menurut Hardjowigeno dan Sukmana (1995) dalam penentuannya menggunakan pendekatan tebal solum tanah yang telah ada dan besarnya erosi sebagai dasar. Sehingga prediksi laju erosi dan klasifikasi tingkat bahaya erosi dapat dilihat dalam Tabel 6. Persebaran kelas tingkat bahaya erosi Desa Tambi dapat dilihat dalam Gambar 1.

Tabel 6. Prediksi Laju Erosi dan Kelas Tingkat Bahaya Erosi

\begin{tabular}{cccccc}
\hline TS & $\begin{array}{c}\text { Satuan } \\
\text { Lahan }\end{array}$ & $\begin{array}{c}\text { Nilai A } \\
\text { (ton/ha/ th) }\end{array}$ & $\begin{array}{c}\text { Solum } \\
\text { Tanah }(\mathbf{c m})\end{array}$ & Kelas TBE & $\begin{array}{c}\text { Luas } \\
\text { Lahan }(\%)\end{array}$ \\
\hline 1 & LT-L & 118,32 & $>90$ & $\mathrm{~S}$ & 30,42 \\
2 & T-AC & 122,63 & $>90$ & $\mathrm{~S}$ & 22,75 \\
3 & LT-D & 186,47 & 65 & $\mathrm{SB}$ & 0,68 \\
4 & LT-AC & 253,40 & $>90$ & $\mathrm{~B}$ & 4,59 \\
5 & KC-AC & 561,19 & 75 & SB & 6,01 \\
6 & KC-L & 139,06 & 45 & $\mathrm{SB}$ & 10,20 \\
7 & LT-C & 45,71 & 80 & $\mathrm{~S}$ & 0,33 \\
8 & KC-C & 522,11 & 55 & SB & 1,92 \\
9 & H-AC & 0,50 & 85 & $\mathrm{R}$ & 8,36 \\
10 & H-C & 1,35 & 80 & $\mathrm{R}$ & 5,89 \\
11 & T-L & 105,32 & $>90$ & $\mathrm{~S}$ & 8,87 \\
\hline
\end{tabular}

Keterangan: $\mathrm{SB}=$ Sangat Berat, $\mathrm{B}=$ Berat, $\mathrm{S}=$ Sedang, $\mathrm{R}=$ Ringan 


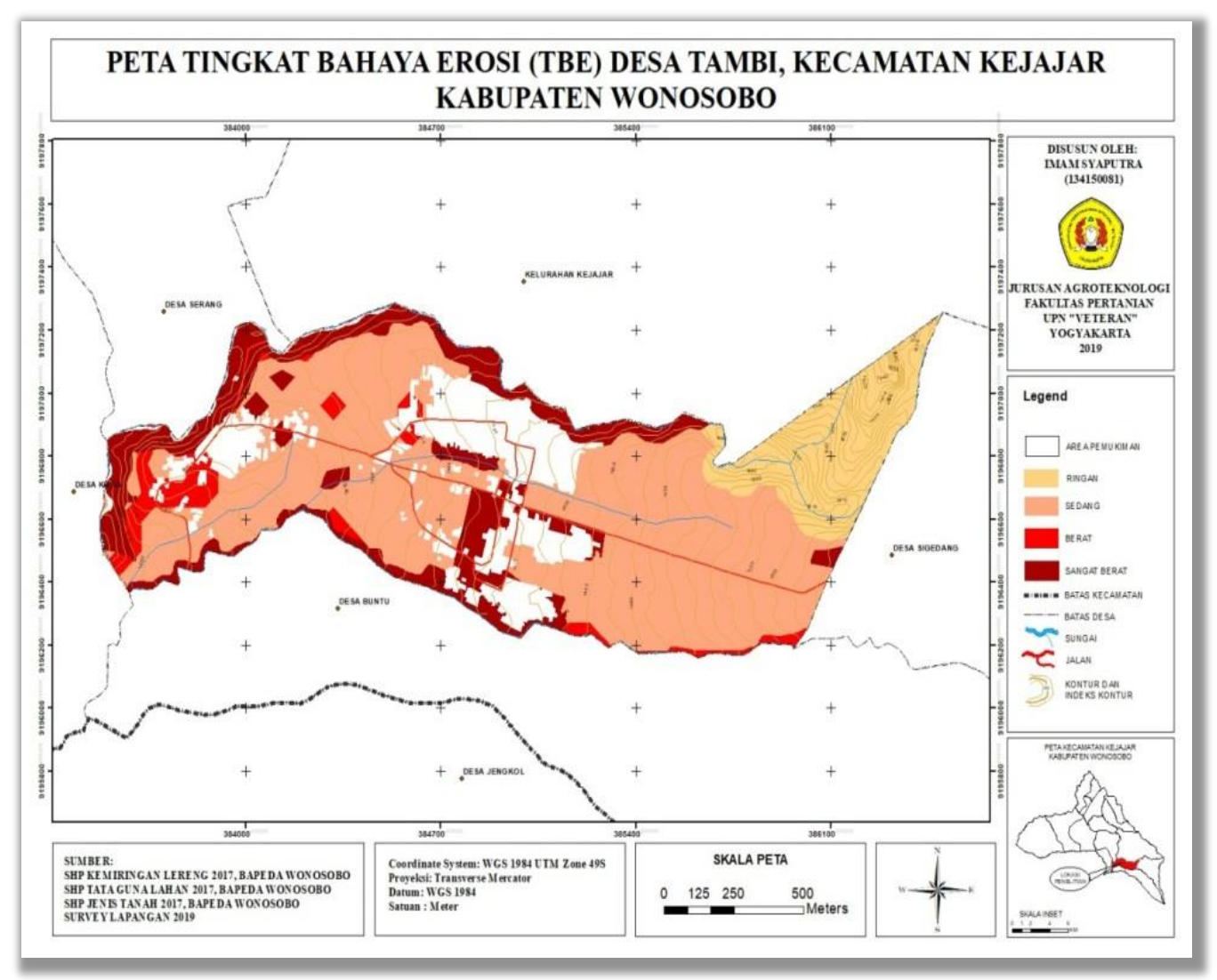

Gambar 1. Peta Tingkat Bahaya Erosi Desa Tambi

Berdasarkan perhitungan laju erosi menggunakan metode USLE dan klasifikasi tingkat bahaya erosi menurut Hardjowigeno dan Sukmana (1995), dapat diketahui bahwa daerah dengan kelas TBE ringan terdapat pada satuan lahan H-AC (TS 9) dan H-C (TS 10) dengan total luasan lahan sebesar 22,66 ha atau 14,24\% dari keseluruhan wilayah Desa Tambi. Kedua satuan lahan ini merupakan hutan produksi dengan penutup lahan yang rapat. Kondisi ini mampu mengurangi energi kinetik air hujan, sehingga memperkecil terjadinya dispersi permukaan tanah. Banyaknya vegetasi penutup tanah juga akan memperbesar infiltrasi dan memperbaiki struktur tanah.

TBE sedang yaitu pada LT-L (TS 1), T-AC (TS 2), LT-C (TS 7) dan T-L (TS11) dengan total luasan lahan sebesar 99,18 ha atau 62,36\% dari keseluruhan wilayah Desa Tambi. Satuan Lahan T-AC (TS 2) dan T-L (TS 11) tergolong pada kelas TBE yang sedang karena perkebunan teh memiliki penutupan lahan yang rapat. Selain daun dari tanaman teh, terdapat juga penutup tanah berupa rumput yang menghalangi air hujan yang turun agar tidak secara langsung jatuh pada permukaan tanah. Dengan adanya hal tersebut, energi kinetik dari air hujan dapat berkurang. Satuan Lahan LT-C (TS 7) memiliki kelas kemiringan lereng yang curam, akan tetapi vegetasi berupa semak belukar mampu menurunkan laju erosi tanah secara efektif serta pembentukan tanah yang sedang yang ditandai dengan kedalaman solum $80 \mathrm{~cm}$ menjadikan satuan lahan ini tergolong pada TBE sedang. Satuan lahan LT-L (TS 1) memiliki laju erosi tinggi yang disebabkan karena tanah yang di dominasi oleh fraksi 
debu dan pasir sangat halus. Akan tetapi pembentukan tanah yang cepat pada wilayah ini menjadikkan satuan lahan LT- T (TS 1) masuk pada kelas TBE sedang.

Satuan lahan yang memiliki kelas TBE berat adalah Satuan Lahan LT-AC (TS 4) dengan luas lahan adalah sebesar 7,30 ha atau 4,59\% dari total keseluruhan wilayah Desa Tambi. Satuan lahan ini memiliki laju erosi tinggi yang disebabkan karena erodibilitas tanah yang tinggi. Selain itu dikarenakan jenis vegetasi berupa tanaman wortel yang tidak menutup tanah secara sempurna. Tindakan konservasi tanah berupa bedengan juga kurang efektif mengingat satuan lahan ini memiliki kelas kemiringan lereng agak curam.

Satuan lahan yang memiliki kelas TBE sangat berat adalah Satuan Lahan LTD (TS 3), KC-AC (TS 5), KC-L (TS 6), dan KC-C (TS 8) dengan total luas lahan adalah sebesar 29,91 ha atau 18,81\% dari keseluruhan wilayah di Desa Tambi. Satuan lahan LT-D (TS 3) ini memiliki nilai erodibilitas tanah (K) yang tinggi. Meskipun kemiringan lereng pada LT-D (TS 3) hanya 6,99\% (datar), tetapi kondisi tanah yang di dominasi oleh fraksi debu dan pasir sangat halus tersebut menjadi peka terhadap air hujan yang turun. Vegetasi berupa tanaman kentang yang ditanam searah kontur dengan tindakan konservasi berupa teras bangku sedang sehingga belum efektif menahan transportasi butiran tanah akibat aliran permukaan (run off. Selain itu, kondisi ketebalan solum yang hanya $65 \mathrm{~cm}$ (dangkal) menunjukkan proses pembentukan tanahnya termasuk lambat. Oleh karena itu, menjadikan satuan lahan LT-D (TS 3) termasuk dalam kategori TBE yang berat.

Satuan lahan KC-L (TS 6) memiliki laju erosi yang besar. Besarnya erosi tersebut diakibatkan oleh beberapa faktor seperti erodibilitas tanah $(\mathrm{K})$ yang tinggi, jenis vegetasi yang dibudidayakan adalah tanaman wortel, tindakan konservasi pada KC-L (TS 6) yang belum maksimal, serta kedalaman solum tanah yang dangkal yaitu hanya $45 \mathrm{~cm}$ yang menunjukkan proses pembentukan tanah pada satuan lahan ini tergolong lambat. Satuan lahan KC-AC (TS 5) dan KC-C (TS 8) memiliki jenis vegetasi yang sama yaitu berupa tanaman tembakau yang dibudidayakan oleh masyarakat (non perkebunan) sehingga memiliki indeks c yang tinggi. Tindakan konservasi yang dilakukan adalah dengan pembuatan teras bangku namun dengan kondisi yang sedang. Kondisi tersebut belum secara efektif dapat menahan dampak dari aliran permukaan (run off), sehingga menjadikan jumlah erosi yang terjadi sangat tinggi. Proses pembentukan tanah pada kedua satuan lahan ini juga tidak terlalu cepat, hal tersebut dapat dilihat dari kedalaman solum tanah pada kedua satuan lahan tersebut yang tergolong dangkal. Oleh karena itu menjadikan kedua satuan lahan ini masuk pada kategori sangat berat.

\section{Simulasi Tingkat Bahaya Erosi}

Pada penelitian ini, dilakukan simulasi menggunakan 5 jenis tanaman yaitu tanaman kacang jogo (Phaseolus vulgaris L.) dengan nilai C sebesar 0,161, tanaman kentang (Solanum tuberosum L.) searah lereng dengan nilai C sebesar 0,9, tanaman kentang (Solanum tuberosum L.) searah kontur dengan nilai C sebesar 0,35, tanaman teh (Camelia sinensis) dengan nilai $\mathrm{C}$ sebesar 0,35, dan tanaman sengon (Paraserianthes falcataria L.) dengan nulai C sebesar 0,0012.

Simulasi dilakukan untuk mengetahui laju erosi yang terjadi serta perubahan klasifikasi tingkat bahaya erosi (TBE). Simulasi dilakukan pada 9 satuan lahan di Desa Tambi yaitu satuan lahan LT-L (TS 1), T- AC (TS 2), LT-D (TS 3), LT-AC (TS 4), KC-AC (TS 5), KC-L (TS 6), LT-C (TS 7), KC-C (TS 8), dan T-L (TS 11). 
Satuan lahan dengan jenis tata guna lahan hutan produksi terbatas tidak dilakukan simulasi, karena mengacu pada Peraturan Pemerintah No. 10 Tahun 2010 bahwa hutan produksi terbatas tidak direkomendasikan adanya perubahan peruntukan maupun fungsi. Tingkat bahaya erosi dari hasil simulasi dapat dilihat pada Tabel 7.

Tabel 7. Hasil Simulasi Tingkat Bahaya Erosi

\begin{tabular}{cccccccc}
\hline \multirow{2}{*}{ TS } & Satuan & \multicolumn{7}{l}{ Tingkat Bahaya Erosi (TBE) } \\
\cline { 3 - 8 } & Lahan & Aktual & KJ & KSL & KSK & T & S \\
\hline 1 & LT-L & S & S & SB & B & S & SR \\
2 & T-AC & S & B & SB & SB & S & SR \\
3 & LT-D & SB & B & SB & SB & B & R \\
4 & LT-AC & B & S & SB & B & B & SR \\
5 & KC-AC & SB & B & SB & SB & SB & R \\
6 & KC-L & SB & SB & SB & SB & SB & S \\
7 & LT-C & S & SB & SB & SB & SB & S \\
8 & KC-C & SB & SB & SB & SB & SB & S \\
11 & T-L & S & B & SB & SB & S & SR \\
\hline Keterangan: KJ = Kacang Jogo; SR = Sangat Ringan; KSL = Kentang Searah \\
\multicolumn{7}{c}{ Lereng; R = Ringan; KSK = Kentang Searah Kontur; S = Sedang; T } \\
\multicolumn{7}{c}{ = Tanaman Teh; B = Berat; S = Tanaman Sengon; SB = Sangat Berat }
\end{tabular}

Simulasi menggunakan berbagai jenis tanaman tidak hanya mempengaruhi laju erosi dan tingkat bahaya erosi yang terjadi, tetapi juga mempengaruhi luas area pada setiap kelas TBE. Simulasi tanaman kacang jogo mengakibatkan adanya penurunan sebesar 27,35\% pada luas area kelas TBE sedang sehingga menjadi 35,01 dari keseluruhan wilayah Desa Tambi, peningkatan sebesar 33,30\% pada luas area kelas TBE berat sehingga menjadi 38,30\% dari keseluruhan wilayah Desa Tambi, dan penurunan sebesar $6,37 \%$ pada luas area kelas TBE sangat berat sehingga menjadi $12,44 \%$ dari keseluruhan wilayah Desa Tambi.

Simulasi tanaman kentang searah kontur mengakibatkan adanya penurunan sebesar 62,36\% atau secara keseluruhan pada luas area kelas TBE sedang, peningkatan sebesar $33,11 \%$ pada luas area kelas TBE berat sehingga menjadi $35,01 \%$ dari keseluruhan wilayah Desa Tambi, dan peningkatan sebesar 31,94\% pada luas area kelas TBE sangat berat sehingga menjadi 50,75\% dari keseluruhan wilayah Desa Tambi.

\section{KESIMPULAN}

1. Simulasi tanaman kentang searah lereng mengakibatkan adanya penurunan secara keseluruhan yaitu sebesar $62,36 \%$ pada luas area kelas TBE sedang, penurunan sebesar 4,90\% atau secara keseluruhan pada luas area kelas TBE berat, dan peningkatan sebesar $66,94 \%$ pada luas area kelas TBE sangat berat sehingga menjadi 85,75\% dari keseluruhan wilayah Desa Tambi.

2. Simulasi tanaman teh mengakibatkan adanya penurunan sebesar $0,33 \%$ pada luas area kelas TBE sedang sehingga menjadi $62,03 \%$ dari keseluruhan wilayah Desa Tambi., peningkatan sebesar $0,37 \%$ pada luas area kelas TBE berat sehingga 
menjadi 5,27\% dari keseluruhan wilayah Desa Tambi., dan penurunan sebesar $0,36 \%$ pada luas area kelas TBE sangat berat sehingga menjadi $18,45 \%$ dari keseluruhan wilayah Desa Tambi.

3. Simulasi Tanaman sengon mengakibatkan adanya kenaikan sebesar $66,62 \%$ atau secara keseluruhan dari luas area kelas TBE sangat ringan, kenaikan sebesar 6,68\% atau secara keseluruhan wilayah pada kelas TBE ringan, dan penurunan sebesar 49,92\% sehingga menjadu 12,44\% dari keseluruhan wilayah Desa Tambi.

4. Desa Tambi memiliki klasifikasi Tingkat Bahaya Erosi (TBE) ringan hingga sangat berat. Satuan lahan dengan Tingkat Bahaya Erosi ringan adalah seluas 22,66 ha atau 14,24\%. Satuan lahan dengan Tingkat Bahaya Erosi sedang adalah seluas 99,18 ha atau $62,36 \%$. Satuan lahan dengan Tingkat Bahaya Erosi berat adalah seluas 7,30 ha atau 4,59\%. Serta satuan lahan dengan Tingkat Bahaya Erosi sangat berat adalah seluas 29,91 ha atau $18,18 \%$.

5. Simulasi tanaman kacang jogo mengakibatkan adanya penurunan sebesar $27,35 \%$ pada luas area kelas TBE sedang, peningkatan sebesar 33,30\% pada luas area kelas TBE berat, dan penurunan sebesar $6,37 \%$ pada luas area kelas TBE sangat berat. Simulasi tanaman kentang searah kontur mengakibatkan adanya penurunan sebesar $62,36 \%$ pada luas area kelas TBE sedang, peningkatan sebesar 33,11\% pada luas area kelas TBE berat, dan peningkatan sebesar $31,94 \%$ pada luas area kelas TBE sangat berat. Simulasi tanaman kentang searah lereng mengakibatkan adanya penurunan sebesar $62,36 \%$ pada luas area kelas TBE sedang,

6. Penurunan sebesar $4,90 \%$ pada luas area kelas TBE berat, dan peningkatan sebesar $66,94 \%$ pada luas area kelas TBE sangat berat. Simulasi tanaman teh mengakibatkan adanya penurunan sebesar $0,33 \%$ pada luas area kelas TBE sedang, peningkatan sebesar $0,37 \%$ pada luas area kelas TBE berat, dan penurunan sebesar $0,36 \%$ pada luas area kelas TBE sangat berat. Simulasi Tanaman sengon mengakibatkan adanya kenaikan sebesar 66,62\% atau secara keseluruhan dari luas area kelas TBE sangat ringan, kenaikan sebesar 6,68\% atau secara keseluruhan wilayah pada kelas TBE ringan, dan penurunan sebesar 49,92\% sehingga menjadu $12,44 \%$ dari keseluruhan wilayah Desa Tambi.

\section{DAFTAR PUSTAKA}

Alie, M.E. 2015. Kajian Erosi Lahan Pada Das Dawas Kabupaten Musi BanyuasinSumatera Selatan. Palembang. Jurnal Teknik Sipil dan Lingkungan Vol. 3, No.1, 1Maret 2015.

Arsyad, S. 1989. Konservasi Tanah dan Air. Institut Pertanian Bogor, Bogor.

Ashari, D. A. 2012. Prediksi Tingkat Bahaya Erosi Di Lahan Tanaman Wortel, Pinus, dan Hutan Desa Gondosuli dan Desa Blambang Kecamatan Tawangmangu [Skripsi]. Surakarta: Universitas Sebelas Maret, Fakultas Pertanian, Jurusan Ilmu Tanah

Hardjoamidjojo, S. dan Sukartaatmadja, S. 1992. Teknik Pengawetan Tanah dan Air. Jica Institut Pertanian Bogor, Bogor.

Hardjowigeno, S dan S. Sukmana. 1995. Menentukan Tingkat Bahaya Erosi.Centre For Soil And Agroclimate Research, Bogor.

Hardjowigeno, S. dan Widiatmaka. 2007. Evaluasi Kesesuaian Lahan dan Perencanaan Tataguna Lahan. Gadjah Mada University Press, Yogyakarta

Kementrian Kehutanan. 2009. Peraturan Menteri Kehutana Republik Indonesia Nomor : 
P. 32/Menhut- Ii/2009 Tentang Tata Cara Penyusunan Rencana Teknik Rehabilitasi Hutan dan Lahan Daerah Aliran Sungai (Rtkrhl- Das). Kementrian Kehutanan RI, Jakarta.

PT Perkebunan Tambi. 2019. Data Curah Hujan Tahun 2009-2019. PT Perkebunan Tambi, Wonosobo

Reijntjes, C., B. Haverkot dan A. W. Bayer, 1999. Pertanian Masa Depan, Pengantar Untuk Pertanian Berkelanjutan Dengan Input Luar Rendah. Kanisius dan Ileia, Yogyakarta.

Schmidt, F. H. \& Ferguson, J. H. (1951). Rainfall Type Based on Wet and Dry Period for Indonesian With Western New Guinea. Kementrian Perhubungan Djawatan Meteorologi dan Geofisika, Jakarta.

Suripin. 2001. Pelestarian Sumber Daya Tanah dan Air. Penerbit Andi Offset, Yogyakarta.

Yuliani, I., S. Wahyuningsih, dan E. Novita. 2015. Identifikas Prioritas Konservasi Berdasarkan Tingkat Bahaya Erosi (TBE) dan Sosial Ekonomi Masyarakat di Kecamatan Pamti Kabupaten Jember. Jurnal Teknologi Pertanian Vol.1, No.1, Juli 2015 